\title{
Effect of different levels of potassium on yield, quality, available nutrient and uptake of blackgram
}

\author{
P.P. KURHADE* ${ }^{*}$ H.N. SETHI ${ }^{1}$ AND R.S. ZADODE \\ Department of Agronomy, Dr. Panjabrao Deshmukh Krishi Vidyapeeth, AKOLA (M.S.) INDIA
}

\begin{abstract}
A field experiment was conducted on PKVU-15 blackgram during the Kharif season of 2013 at Pulse Research Unit, Dr. Panjabrao Deshmukh Krishi Vidyapeeth, Akola to study the effect of potassium on yield, quality, available nutrient status and its uptake of blackgram. Yield quality, nutrient status and its uptake of blackgram were significantly increased due to increased level of potassium fertilizer. RDF +40 $\mathrm{kg} \mathrm{K}_{2} \mathrm{O} \mathrm{ha}^{-1}$ significantly improved the quality of seed, available nutrient status and nutrient uptake of blackgram over the application of RDF only. Treatment $\mathrm{RDF}+40 \mathrm{~kg} \mathrm{~K}_{2} \mathrm{O} \mathrm{ha}^{-1}$ was at par with $\mathrm{RDF}+30 \mathrm{~kg} \mathrm{~K}_{2} \mathrm{O} \mathrm{ha}^{-1}$ and $\mathrm{RDF}+20 \mathrm{~kg} \mathrm{~K}_{2} \mathrm{O} \mathrm{ha}^{-1}$, treatment $\mathrm{RDF}+\mathrm{Foliar}$ spray of KCl 1.5 per cent (at flowering and 10-15 days after flowering) significantly improved the quality of blackgram and nutrient uptake over the application of RDF (20:40 N:P kg ha-1) only. This treatment was at par with soil applied RDF+ $20 \mathrm{~kg} \mathrm{~K}_{2} \mathrm{O} \mathrm{ha}^{-1}$.
\end{abstract}

Key Words : Blackgram, Foliar spray, Nutrient uptake, Quality, Potassium

View Point Article : Kurhade, P.P., Sethi, H.N. and Zadode, R.S. (2015). Effect of different levels of potassium on yield, quality, available nutrient and uptake of blackgram. Internat. J. agric. Sci., 11 (1): 175-178.

Article History : Received : 13.11.2014; Revised : 07.12.2014; Accepted : 21.12.2014

\footnotetext{
* Author for correspondence

${ }^{1}$ Central Demonstration Farm, Wani Rambhapur, AKOLA (M.S.) INDIA
} 